\title{
MULTIVARIATE SPECTROPHOTOMETRIC ANALYSIS OF CERTAIN ANTIHYPERTENSIVE BINARY MIXTURES
}

\author{
Abd El-Maaboud I.Mohamed*, Samiha A. Hussein and Hanaa M. Abdel-Wadood \\ Department of Pharmaceutical Analytical Chemistry, Faculty of Pharmacy, \\ Assiut University, Assiut, Egypt
}

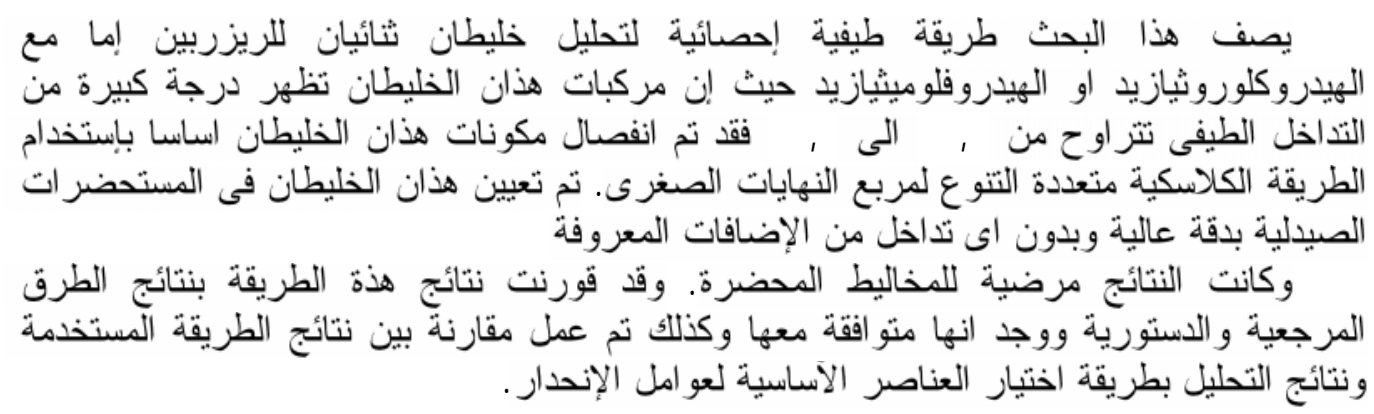

A multivariate calibration method for the analysis of two hypotensive binary mixtures is described. The mixtures are composed of reserpine in combination either with hydrochlorothiazide or hydrofluomethiazide respectively. The components of the two mixtures show a considerable degree of spectral overlapping (83.5-88.5\%). Resolution of the binary mixtures under investigation has been accomplished mainly by using classical least squares $(C L S)$ analysis. The mixtures are simultaneously determined in three laboratory prepared tablet forms with high accuracy without interference from the commonly added excipients. Good recoveries were obtained with both synthetic mixtures and prepared tablets. The obtained results were compared with those obtained from official methods and found in good agreement with them. A comparison of the obtained results from CLS were performed with those obtained from principle component regression (PCR).

\section{INTRODUCTION}

Reserpine and its preparations still remain useful in control of mild essential hypertension. It is effective orally and parentrally in the treatment of hypertension. Reserpine also used in conjunction with other hypotensive drugs in the treatment of severe hypertension. ${ }^{1,2}$ On the other hand, hydrochlorothiazide and hydrofluomethiazide are mild antihypertensive diuretic drugs. They are useful alone in management of mild hypertension by reducing the blood volume or in combination with other classes of hypotensive agents in case of the more severe cases. Binary mixtures of reserpine with hydrochlorothiazide or hydrofluomethiazide are examples of such combinations which still in common use. ${ }^{1-4}$

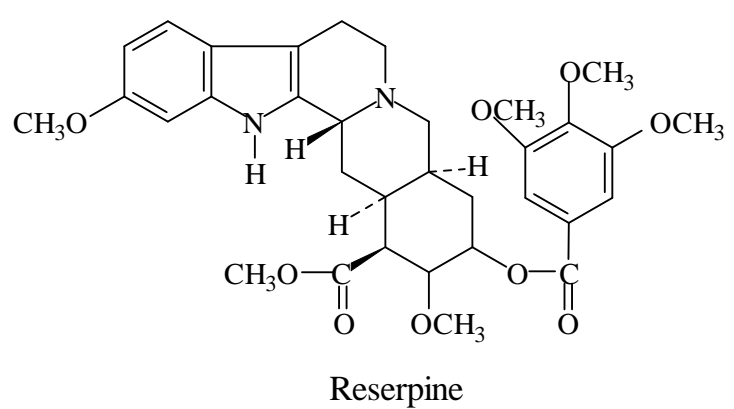<smiles>[X]c1cc2c(cc1S(N)(=O)=O)S(=O)(=O)NCC2N</smiles> 
Many reported methods for the determination of the targeted drugs are present in literature. Reported procedures included classical titrimetric, ${ }^{5,6}$ electrochemical, ${ }^{7,8}$ spectrophotometric, ${ }^{4,9-13}$ spectrofluorimetric, ${ }^{4,14,15}$ chromatographic, ${ }^{16-18}$ and other separation techniques. ${ }^{19-21}$ Simultaneous determination of studied drugs in certain commercial combined formulations by derivative spectroscopy, ${ }^{22-24}$ ratio-spectra derivative spectrophotometry and Vierordt's methods, ${ }^{25-27}$ HPLC, ${ }^{28-30}$ flow injection dynamic systems $^{14,31,32}$ and chemometric methods ${ }^{33,34}$ were also reported.

Multivariate calibration methods applied to spectral data are being increasingly used for pharmaceutical analysis. ${ }^{35-40}$ Classical least squares (CLS) analysis is one of the simplest multivariate methods that can be performed with easily accessible statistical software. In the present work we discuss the possibility of simultaneous analysis of combined formulations of reserpine with either hydrochlorothiazide or hydrofluomethiazide in certain antihypertension mixtures. The method is based on the spectrophotometric measurements in the general range of 240-320 $\mathrm{nm}$ together with multivariate calibration analysis. The obtained results showed that CLS regression allows one to accomplish this goal, whereas the used method gives quite satisfactory results when compared to those obtained with PCR and shows that there is no need to use any additional statistical treatments. Results were also compared to those obtained by reported procedures for the same combinations and the required statistical parameters were calculated.

\section{EXPERIMENTAL}

\section{Apparatus}

Spectrophotometric measurements were carried out on a computerized UV-1601 PC, UV-visible Shimadzu spectrophotometer (Tokyo-Japan), using $1.00 \mathrm{~cm}$ quartz cells. The obtained spectral data were saved in PC Shimadzu program and the subsequent statistical manipulation was performed by transferring the spectral data to Microsoft excel 2000 program and processing them with the standard curve fit package and matrix calculations.

\section{Chemicals}

Pharmaceutical grade reserpine (Memphis, Cairo, Egypt), hydrochlorothiazide (Kahira Pharmaceutical and Chemical Industries, Cairo, Egypt) and hydrofluomethiazide (Kahira Pharmaceutical and Chemical Industries, Cairo, Egypt) were used as working standards after confirming their purity and compliance with the pharmaceutical requirements. All solvents used throughout this work were analytical grade.

\section{Laboratory prepared Tablets}

Commercial tablets contain reserpine in concentration range from 0.1 to $0.25 \mathrm{mg}$ compared to 25-30 $\mathrm{mg}$ for either hydrochlorothiazide or hydrofluomethiazide (i.e. about $0.3-1.0 \%$ ). Thus, in the dilutions suitable for hydrochlorothiazide and hydrofluomethiazide calibration ranges, reserpine concentration is too small and cannot be determined precisely. Therefore, the following tablets are prepared in our laboratory and subjected to analysis by the proposed procedure;

T.I: Prepared to contain reserpine $(5 \mathrm{mg})$ and hydrochlorothiazide $(25 \mathrm{mg})$.

T.II: Prepared to contain reserpine $(5 \mathrm{mg})$ and hydrofluomethiazide $(25 \mathrm{mg})$

T.III: Prepared to contain reserpine $(5 \mathrm{mg})$ and hydrofluomethiazide $(30 \mathrm{mg})$.

All formulations containing lactose (100 mg), starch $(100 \mathrm{mg})$, magnesium stearate $(5 \mathrm{mg})$, talc (5-10 $\mathrm{mg})$ and gum tragacance $(5 \mathrm{mg})$.

\section{Preparation of standards}

Dissolve an accurately weighed amount $(50 \mathrm{mg})$ of either reserpine, hydrochlorothiazide or hydrofluomethiazide in methanol and dilute quantitatively with the same solvent to obtain the appropriate dilution for each drug according to its linear calibration range.

\section{Preparation of tablet samples}

Weigh 20 tablets and finely powder. Transfer accurately weighed amount of the powder equivalent to one tablet to $100 \mathrm{ml}$ volumetric flask and dilute to about $80 \mathrm{ml}$ with methanol. Shake the mixture well for about 10 minutes, dilute to the mark with the same solvent and filter. Discard the first portion of filtrate. Use clear solution obtained as stock sample solution. Dilute stock solution quantitatively with methanol to obtain the 
suitable working sample solution for UVmeasurements.

\section{Standard solutions for multivariate calibration}

In order to obtain the calibration matrix for applying CLS and PCR analysis, ten solutions of each of the pure components (reserpine, hydrochlorothiazide and hydrofluomethiazide) were prepared with concentrations in the range 5-60, 5-30 and 5-30 $\mu \mathrm{g} / \mathrm{ml}$ respectively. These ranges were previously verified to obey Beer's law for each of the studied drugs in the selected solvent. The absorption data in the range of 240-320 nm (digitized every $1.0 \mathrm{~nm}$ ) were subjected to least squares analysis in order to obtain the calibration K matrix (see below). Laboratory prepared mixtures were then prepared by mixing known amounts of reserpine with either hydrochlorothiazide or hydrofluo-methiazide in different varied proportions (Tables 1 and 2), in order to verify the precision of the method for analysis of such mixtures and matching the prepared tablets with those having comparable concentrations.

\section{Data processing}

Data were processed on an Intel Pentium III $750 \mathrm{MHz}$ PC-compatible computer. The VISTA 6 version 6.4.3436-EWU (May 10, 2001) software was used for the Principal component applications. The parameters chosen to compare the different models were the relative root mean squared error (RRMSE) and the standard deviation of the model fitness $\left(\sigma_{\text {fit }}\right)$ :

$$
\operatorname{RRMSE}(\%)=100 \times \sqrt{\frac{\sum\left(\mathrm{C}_{\mathrm{i}}-\hat{\mathrm{C}}_{\mathrm{i}}\right)^{2}}{\sum \mathrm{C}_{\mathrm{i}}^{2}}}
$$

Where $\hat{C}_{i}$ and $C_{i}$ are the predicted and the real concentrations respectively, for the compound in the standard or sample solutions.

$$
\sigma_{\text {fit }}=\sqrt{\left(\mathrm{A}_{\text {act }}-\mathrm{A}_{\text {pred }}\right)^{2} / \mathrm{n}-2}
$$

Where $\mathrm{n}$ is the number of data points for the two component mixture, and $\mathrm{A}=\mathrm{K}_{1} \mathrm{C}_{1}+\mathrm{K}_{2}$ $\mathrm{C}_{2}$, being $\mathrm{K}_{1}$ and $\mathrm{K}_{2}$ the column vector of the individual component absorptivities.

\section{RESULTS AND DISCUSSION}

The absorption spectra for the studied drugs are shown in Figure 1. As can be seen, a considerable degree of spectral overlapping occurs in the region from 240 to $320 \mathrm{~nm}$. The degree of spectral overlapping can be conveniently given by $\left(\mathrm{D}_{\mathrm{i}}\right)^{0.5}$. Where $\mathrm{D}_{\mathrm{i}}$ is the magnitude of dependency that can be calculated for a two components mixture from equation (3).

$$
\operatorname{Di}=\frac{\left(\Sigma \mathrm{k}_{1} \mathrm{k}_{2}{ }^{\mathrm{t}}\right)^{2}}{\Sigma \mathrm{k}_{1} \mathrm{k}_{1}{ }^{\mathrm{t}} \cdot \Sigma \mathrm{k}_{2} \mathrm{k}_{2}{ }^{\mathrm{t}}}
$$

Where $\mathrm{K}_{1}$ and $\mathrm{K}_{2}$ are the $l \times n$ matrices of regression coefficients for compounds 1 and 2 respectively.

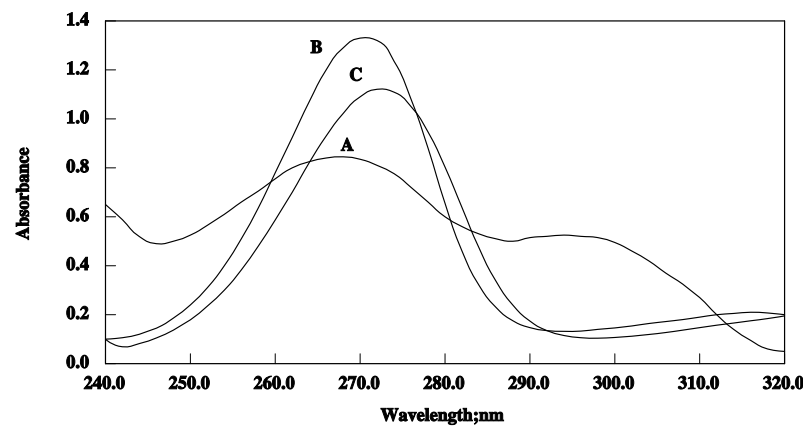

Fig. 1: The absorption spectra of (A) reserpine (30 $\mu \mathrm{g} / \mathrm{ml})(\mathbf{B})$ hydrochlorothiazide $(20 \mu \mathrm{g} / \mathrm{ml})$ and (C) hydrofluomethiazide $(20 \mu \mathrm{g} / \mathrm{ml})$

In case of the presently studied compounds, the spectra shown in Figure 1 lead to $\mathrm{Di}=0.700$ implying a $83.5 \%$ of spectral overlap for the first mixture (reserpine and hydrochlorothiazide) and $\mathrm{Di}=0.784$, implying a $88.5 \%$ of spectral overlap for the second mixture (reserpine and hydrofluomethiazide) respectively.

Derivative spectrophotometric techniques can not precisely resolved these mixtures. Fullspectrum methods usually provide significant improvement in precision over methods restricted to a small number of wavelengths. A convenient method for resolving the mixtures, which can in principle be applied to the present case, is the least squares analysis. The simplest of them is the classical least squares (CLS). It should certainly be preferred when the selection of variables is simple, i.e. when some 
Table 1: Results obtained by applying CLS analysis to synthetic mixtures and laboratory prepared tablets of reserpine and hydrochlorothiazide.

\begin{tabular}{|c|c|c|c|c|c|c|}
\hline \multirow{2}{*}{$\begin{array}{l}\text { Mix- } \\
\text { ture }\end{array}$} & \multirow{2}{*}{ Component } & \multirow{2}{*}{$\begin{array}{l}\text { Actual } \\
(\mu \mathrm{g} / \mathrm{ml})\end{array}$} & \multicolumn{2}{|c|}{ Found } & \multirow{2}{*}{$\begin{array}{c}\mathrm{RRMSE}^{+} \\
(\%)\end{array}$} & \multirow{2}{*}{$\sigma_{\mathrm{fit}}{ }^{*}$} \\
\hline & & & $(\mu \mathrm{g} / \mathrm{ml})$ & $(\%)$ & & \\
\hline \multirow{2}{*}{ (1) } & Reserpine & 60.00 & 58.90 & 98.2 & 1.8 & 0.019 \\
\hline & Hydrochlorothiazide & 5.00 & 4.91 & 98.2 & 1.8 & \\
\hline \multirow{2}{*}{ (2) } & Reserpine & 50.00 & 50.22 & 100.4 & 0.4 & 0.013 \\
\hline & Hydrochlorothiazide & 7.50 & 7.37 & 98.3 & 1.7 & \\
\hline \multirow{2}{*}{ (3) } & Reserpine & 45.00 & 43.69 & 97.1 & 2.9 & 0.027 \\
\hline & Hydrochlorothiazide & 10.00 & 9.72 & 97.2 & 2.8 & \\
\hline \multirow{2}{*}{ (4) } & Reserpine & 40.00 & 39.69 & 99.2 & 0.8 & 0.0018 \\
\hline & Hydrochlorothiazide & 12.50 & 12.22 & 97.8 & 2.2 & \\
\hline \multirow{2}{*}{ (5) } & Reserpine & 35.00 & 34.32 & 98.1 & 1.9 & 0.014 \\
\hline & Hydrochlorothiazide & 15.00 & 14.89 & 99.3 & 0.7 & \\
\hline \multirow{2}{*}{ (6) } & Reserpine & 30.00 & 29.99 & 100.0 & 0.0 & 0.008 \\
\hline & Hydrochlorothiazide & 17.50 & 17.33 & 99.0 & 1.0 & \\
\hline \multirow{2}{*}{ (7) } & Reserpine & 20.00 & 19.53 & 97.6 & 2.4 & 0.026 \\
\hline & Hydrochlorothiazide & 20.00 & 19.55 & 97.7 & 2.3 & \\
\hline \multirow{2}{*}{ (8) } & Reserpine & 15.00 & 15.16 & 101.1 & 1.1 & 0.009 \\
\hline & Hydrochlorothiazide & 22.50 & 22.49 & 100.0 & 0.0 & \\
\hline \multirow{2}{*}{ (9) } & Reserpine & 10.00 & 9.87 & 98.7 & 1.3 & 0.011 \\
\hline & Hydrochlorothiazide & 25.00 & 24.93 & 99.7 & 0.3 & \\
\hline \multirow{2}{*}{$(10)$} & Reserpine & 5.00 & 4.93 & 98.6 & 1.4 & 0.012 \\
\hline & Hydrochlorothiazide & 25.00 & 24.88 & 99.5 & 0.5 & \\
\hline \multirow{2}{*}{ (I) } & Reserpine & 5.00 & 5.06 & 101.2 & 1.2 & 0.014 \\
\hline & Hydrochorothiazide & 25.00 & 25.32 & 101.3 & 1.3 & \\
\hline
\end{tabular}

$+\operatorname{RRMSE}(\%)=100 X \sqrt{\Sigma\left(\mathrm{C}_{\mathrm{i}}-\hat{\mathrm{C}}_{\mathrm{i}}\right)^{2} \sum \mathrm{C}_{\mathrm{i}}^{2}}$.

$* \sigma_{\text {fit }}=\left[\left(a_{\text {act }}-a_{\text {pred }}\right)^{2} / n-2\right]^{0.5}$, Where $n=$ number of data points for the two component mixture, $\mathrm{a}=\mathrm{K}_{1} \mathrm{C}_{1}+\mathrm{K}_{2} \mathrm{C}_{2}, \mathrm{~K}_{1,2}$ being the column vector of individual component absorptivities.

(I) Laboratory prepared Tablets (I). 
Table 2: Results obtained by applying CLS analysis to synthetic mixtures and laboratory prepared tablets of reserpine and hydrofluomethiazide.

\begin{tabular}{|c|c|c|c|c|c|c|}
\hline \multirow{2}{*}{$\begin{array}{l}\text { Mix- } \\
\text { ture }\end{array}$} & \multirow{2}{*}{ Component } & \multirow{2}{*}{$\begin{array}{l}\text { Actual } \\
(\mu \mathrm{g} / \mathrm{ml})\end{array}$} & \multicolumn{2}{|c|}{ Found } & \multirow{2}{*}{$\begin{array}{c}\text { RRMSE }^{+} \\
(\%)\end{array}$} & \multirow{2}{*}{$\sigma_{\mathrm{fit}}{ }^{*}$} \\
\hline & & & $(\mu \mathrm{g} / \mathrm{ml})$ & $(\%)$ & & \\
\hline \multirow{2}{*}{ (1) } & Reserpine & 60.00 & 59.07 & 98.5 & 1.5 & 0.019 \\
\hline & Hydrofluomethiazide & 5.00 & 5.08 & 101.7 & 1.7 & \\
\hline \multirow{2}{*}{ (2) } & Reserpine & 50.00 & 49.40 & 98.8 & 1.2 & 0.009 \\
\hline & Hydrofluomethiazide & 10.00 & 10.02 & 100.2 & 0.2 & \\
\hline \multirow{2}{*}{ (3) } & Reserpine & 45.00 & 44.05 & 97.9 & 2.1 & 0.018 \\
\hline & Hydrofluomethiazide & 12.50 & 12.44 & 99.5 & 0.5 & \\
\hline \multirow{2}{*}{ (4) } & Reserpine & 35.00 & 34.97 & 99.9 & 0.1 & 0.004 \\
\hline & Hydrofluomethiazide & 15.00 & 14.99 & 99.9 & 0.1 & \\
\hline \multirow{2}{*}{ (5) } & Reserpine & 30.00 & 29.53 & 98.4 & 1.6 & 0.014 \\
\hline & Hydrofluomethiazide & 17.50 & 17.62 & 100.7 & 0.7 & \\
\hline \multirow{2}{*}{ (6) } & Reserpine & 25.00 & 24.89 & 99.6 & 0.4 & 0.005 \\
\hline & Hydrofluomethiazide & 20.00 & 19.98 & 99.9 & 0.1 & \\
\hline \multirow{2}{*}{ (7) } & Reserpine & 20.00 & 20.17 & 100.9 & 0.9 & 0.013 \\
\hline & Hydrofluomethiazide & 22.50 & 22.88 & 101.7 & 1.7 & \\
\hline \multirow{2}{*}{ (8) } & Reserpine & 15.00 & 14.76 & 98.4 & 1.6 & 0.011 \\
\hline & Hydrofluomethiazide & 25.00 & 25.06 & 100.2 & 0.2 & \\
\hline \multirow{2}{*}{ (9) } & Reserpine & 10.00 & 9.81 & 98.1 & 1.9 & 0.017 \\
\hline & Hydrofluomethiazide & 30.00 & 29.65 & 98.8 & 1.2 & \\
\hline \multirow{2}{*}{$(10)$} & Reserpine & 5.00 & 4.90 & 98.0 & 2.0 & 0.021 \\
\hline & Hydrofluomethiazide & 30.00 & 29.49 & 98.3 & 1.7 & \\
\hline \multirow{2}{*}{ (II) } & Reserpine & 5.00 & 4.89 & 97.8 & 2.2 & 0.017 \\
\hline & Hydrofluomethiazide & 25.00 & 25.09 & 100.4 & 0.4 & \\
\hline \multirow{2}{*}{ (III) } & Reserpine & 5.00 & 5.10 & 102.0 & 2.0 & 0.018 \\
\hline & Hydrofluomethiazide & 30.00 & 29.77 & 99.2 & 0.8 & \\
\hline
\end{tabular}

$+\operatorname{RRMSE}(\%)=100 \mathrm{X} \sqrt{\Sigma\left(\mathrm{C}_{\mathrm{i}}-\hat{\mathrm{C}}_{\mathrm{i}}\right)^{2} \sum \mathrm{C}_{\mathrm{i}}^{2}}$.

$* \sigma_{\text {fit }}=\left[\left(a_{\text {act }}-a_{\text {pred }}\right)^{2} / n-2\right]^{0.5}$, Where $\mathrm{n}=$ number of data points for the two component mixture,

$\mathrm{a}=\mathrm{K}_{1} \mathrm{C}_{1}+\mathrm{K}_{2} \mathrm{C}_{2}, \mathrm{~K}_{1,2}$ being the column vector of individual component absorptivities.

(II) and (III) Laboratory prepared Tablets (II) and (III). 
variables are rather selective for the compounds or characteristics being determined. In addition, the regression coefficients for different selected collinear wavelengths may have relatively little meaning for interpretation purposes, but the model performs well, both in calibration and in prediction, provided that the model possess linearity between response and concentration and the prediction is performed within the calibration domain. On the other hand, the baseline effects and noise are probably non-significant or of very low significance. Under these conditions, CLS is probably the method to be recommended as in the present work.

As mentioned previously in CLS a linear relationship between the absorbance and the component concentrations at each wavelength is assumed. Such relationship is given by equation (4).

$$
\mathrm{A}=\mathrm{C} \mathrm{K}+\mathrm{E}
$$

Where $\mathrm{A}$ is the $m x n$ matrix of calibration spectra, $\mathrm{C}$ is the $m \times l$ matrix of component concentrations, $\mathrm{K}$ is the $l x n$ matrix of regression coefficients and $\mathrm{E}$ is the $m x n$ matrix of spectral errors or residuals not fit by the model. By means of the calibration sample set, estimation of absorptivities is possible by solving for the matrix $\mathrm{K}$ according to the general least-squares solution indicated by equation (5).

$$
\mathrm{K}=\left(\mathrm{C}^{\mathrm{t}} \cdot \mathrm{C}\right)^{-1} \cdot \mathrm{C}^{\mathrm{t}} \cdot \mathrm{A}
$$

Analysis is then based on the spectrum $\left(\mathrm{A}_{\mathrm{un}}\right)$ of the unknown samples by:

$$
\mathrm{C}_{\mathrm{un}}=\mathrm{A}_{\mathrm{un}} \mathrm{K}^{\mathrm{t}}\left(\mathrm{K} \cdot \mathrm{K}^{\mathrm{t}}\right)^{-1}
$$

Where $\mathrm{C}_{\mathrm{un}}$ is the vector of sought-for concentrations.

Figures 2-4 showed the actual and predicted amounts of the studied drugs given by the least squares regression analysis of the spectral data that obtained experimentally in the range of $240-320 \mathrm{~nm}$.

Several synthetic mixtures and the prepared tablets were subjected to the CLS analysis. Tables 1 and 2 summarize the results obtained for the suggested synthetic binary mixtures. As can be seen, the recoveries in

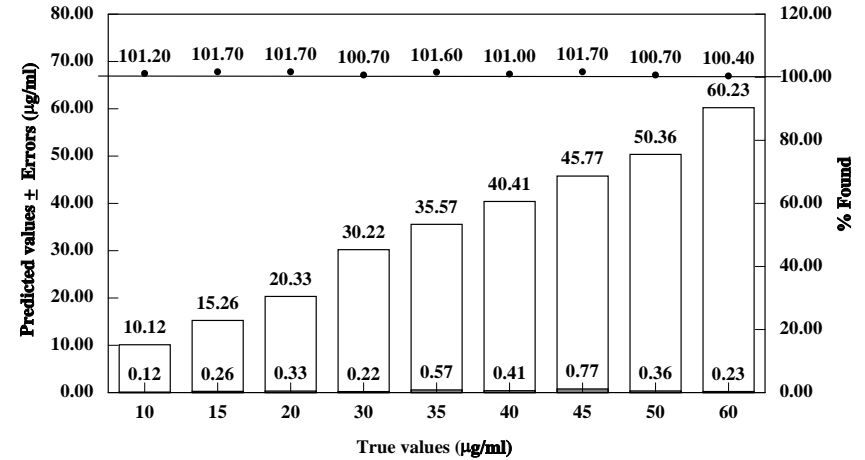

Fig. 2: Predicted concentrations of reserpine \pm errors as calculated by GLS method.

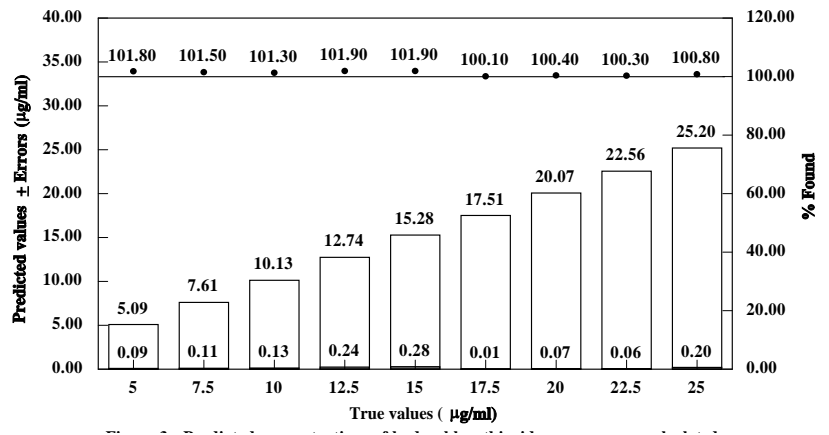

Fig. 3: Predicted concentrations of hydrochlorothiazide \pm errors as calculated by GLS method.

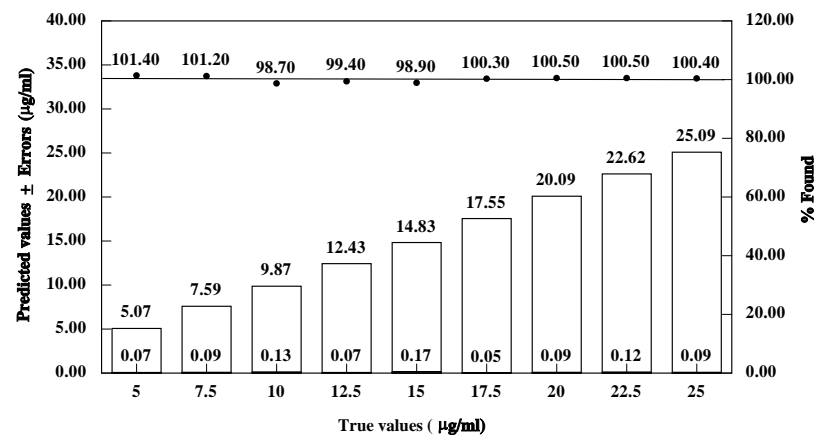

Fig. 4: Predicted concentrations of hydrofluomethiazide \pm errors as calculated by GLS method.

all cases were satisfactory and the relative deviations between the estimated and true concentrations expressed by the relative root mean squared error (RRMSE) were found between 0.3 and $2.9 \%$.

On the other hand, the results for synthetic mixtures and prepared tablets with comparable concentrations were found closely matched. This indicated that, the present or added excipients and additives did not interfere with 
the determinations. Moreover, the results for dosage forms were compared with those obtained by applying official methods ${ }^{4}$. As shown in Table 3, the results are in good agreement with those of official procedures as indicated by the t-test.

Principle component regression (PCR), were also applied for analysis of the present samples. A comparison between the results obtained with PCR and that obtained with CLS was done. It revealed that, there was no significant difference between them as indicated by the representative example given in Table 4. It should be mentioned also that, when co linearity between original variables occurs, principal component plots often allow better interpretation of the variations observed in the data set than plots of original variables selected by CLS. But, as a modeling method, it is somewhat less per-formant than CLS when performing prediction within the calibration domain and when the model is indeed linear. Accordingly, the results of analysis obtained in this work by the CLS are quite satisfactory and there is no need to use additional statistical treatments.

\section{Conclusion}

The contents of several synthetic mixtures and prepared tablets were simultaneously determined using spectrophotometric measurements together with CLS multivariate calibration analysis. The good recoveries obtained in all cases as well as the reliable agreement with the official procedures proved that, the proposed method could be applied efficiently for determination of reserpine binary mixtures with either hydrochlorothiazide or hydrofluomethiazide with quite satisfactory precision.

Table 3: Analysis of the studied drugs in laboratory prepared tablets by the CLS and official methods*.

\begin{tabular}{|c|c|c|c|c|}
\hline $\begin{array}{c}\text { Laboratory } \\
\text { prepared } \\
\text { tablets } \\
\end{array}$ & Drug & $\begin{array}{l}\text { Claimed } \\
\text { (mg) }\end{array}$ & $\begin{array}{l}\text { Found } \\
\qquad(\% \pm \mathrm{SD})\end{array}$ & $\begin{array}{l}\text { USP XXIII } \\
(\% \pm \text { SD) }\end{array}$ \\
\hline \multirow{2}{*}{ I } & \multicolumn{4}{|c|}{$\mathrm{F}=3.45, \mathrm{t}=2.30$} \\
\hline & Hydrochlorothiazide & 25 & $\begin{array}{c}25.32 \quad 101.3 \pm 1.7 \\
\mathrm{~F}=3.57, \mathrm{t}=1.14\end{array}$ & $100.2 \pm 0.9$ \\
\hline \multirow{2}{*}{ II } & \multicolumn{4}{|c|}{$\mathrm{F}=4.00, \mathrm{t}=1.12$} \\
\hline & Hydroflumethiazide & 25 & $\begin{array}{c}25.09 \quad 100.4 \pm 0.8 \\
\mathrm{~F}=2.25, \mathrm{t}=2.63\end{array}$ & $98.5 \pm 1.2$ \\
\hline \multicolumn{5}{|c|}{$\begin{array}{c}5.10 \quad 102.0 \pm 1.9 \\
\mathrm{~F}=1.60, \mathrm{t}=1.21\end{array}$} \\
\hline 11 & Hydrofluomethiazide & 30 & $\begin{array}{c}29.77 \quad 99.2 \pm 0.9 \\
F=2.25, t=2.40\end{array}$ & $97.4 \pm 0.6$ \\
\hline
\end{tabular}

* Average of 5 determinations \pm SD.

+ Theoretical values at $95 \%$ confidence limit are $\mathrm{t}=2.78$ and $\mathrm{F}=6.39$. 
Table 4: Results obtained by applying CLS and PCR to synthetic mixtures of reserpine and hydrochlorothiazide.

\begin{tabular}{|c|c|c|c|c|c|c|}
\hline $\begin{array}{l}\text { Mixt- } \\
\text { ure }\end{array}$ & Component & $\begin{array}{l}\text { Actual } \\
(\mu \mathrm{g} / \mathrm{ml})\end{array}$ & $\begin{array}{c}\text { CLS } \\
(\mu \mathrm{g} / \mathrm{ml})\end{array}$ & $\begin{array}{c}\text { Relative error } \\
(\%)\end{array}$ & $\begin{array}{c}\text { PCR } \\
(\mu \mathrm{g} / \mathrm{ml})\end{array}$ & $\begin{array}{c}\text { Relative error } \\
(\%)\end{array}$ \\
\hline \multirow{2}{*}{ (1) } & Reserpine & 60.00 & 58.90 & -1.83 & 59.12 & -1.47 \\
\hline & Hydrochlorothiazide & 5.00 & 4.91 & -1.80 & 4.89 & -2.20 \\
\hline \multirow{2}{*}{ (2) } & Reserpine & 50.00 & 50.22 & 0.44 & 50.30 & 0.60 \\
\hline & Hydrochlorothiazide & 7.50 & 7.37 & -1.73 & 7.41 & -1.20 \\
\hline \multirow{2}{*}{ (3) } & Reserpine & 45.00 & 43.69 & -2.91 & 43.77 & -2.73 \\
\hline & Hydrochlorothiazide & 10.00 & 9.72 & -2.80 & 9.68 & -3.20 \\
\hline \multirow{2}{*}{ (4) } & Reserpine & 40.00 & 39.69 & -0.78 & 40.11 & 0.28 \\
\hline & Hydrochlorothiazide & 12.50 & 12.22 & -2.24 & 12.34 & -1.28 \\
\hline \multirow{2}{*}{ (5) } & Reserpine & 35.00 & 34.32 & -1.94 & 34.13 & -2.49 \\
\hline & Hydrochlorothiazide & 15.00 & 14.89 & -0.73 & 15.01 & 0.07 \\
\hline \multirow{2}{*}{ (6) } & Reserpine & 30.00 & 29.99 & -0.03 & 30.12 & 0.40 \\
\hline & Hydrochlorothiazide & 17.50 & 17.33 & -0.97 & 17.52 & 0.11 \\
\hline \multirow{2}{*}{ (7) } & Reserpine & 20.00 & 19.53 & -2.35 & 19.55 & -2.25 \\
\hline & Hydrochlorothiazide & 20.00 & 19.55 & -2.25 & 20.10 & 0.50 \\
\hline \multirow{2}{*}{ (8) } & Reserpine & 15.00 & 15.16 & 1.07 & 15.06 & 0.40 \\
\hline & Hydrochlorothiazide & 22.50 & 22.49 & -0.04 & 22.55 & 0.22 \\
\hline \multirow{2}{*}{ (9) } & Reserpine & 10.00 & 9.87 & -1.30 & 9.88 & -1.20 \\
\hline & Hydrochlorothiazide & 25.00 & 24.93 & -0.28 & 24.61 & -1.56 \\
\hline \multirow{2}{*}{ (10) } & Reserpine & 5.00 & 4.93 & -1.40 & 4.89 & -2.20 \\
\hline & Hydrochlorothiazide & 25.00 & 24.88 & -0.48 & 24.93 & -0.28 \\
\hline \multirow{2}{*}{ (I) } & Reserpine & 5.00 & 5.06 & 1.2 & 5.07 & 1.4 \\
\hline & Hydrochlorothiazide & 25.00 & 25.32 & 1.3 & 25.21 & 0.84 \\
\hline
\end{tabular}

(I) Laboratory prepared Tablets (I).

\section{REFERENCES}

1- J. N. Delgado and W. A. Remers; "Wilson and Gisvold's Textbook of Organic Medicinal and Pharmaceutical Chemistry“, $10^{\text {th }}$ Edition, J.B. Lippincott Company, London and New York, pp. 484,608 and 609 (1998).

2- W. O. Foye, T. L. Lemke and D. A. Williams; "Principles of Medicinal Chemistry", $4^{\text {th }}$ Edition, Lea and Febiger, Philadelphia, pp. 9, 363 (1995).

3- M. E. Wolff; "Burger's Medicinal Chemistry "Part 2, $5^{\text {th }}$ Edition, J.Wiley and sons, New York, p. 279 (1997).
4- United States Pharmacopeia XXIII and NF XVIII, American Pharmaceutical Association, Washington, DC, pp. 766, 1375 and 1376 (1995).

5- British Pharmacopoeia, Her Majesty's Stationary Office, London, UK, (1980).

6- L. Przyborowski and G. Pionka; Farmacia Pol., 32, 399 (1976) 399, Anal. Abstr., 31, 5E64 (1976).

7- A. L. Woodson and D. E. Smith, Anal. Chem., 42. 242 (1970).

8- E. Kkolos and J. Walker, Anal. Chim. Acta, 80. 17 (1975).

9- A.-M.I. Mohamed, Talanta, 35, 621 (1988). 
10- A. F. Youssef, S. R. El-Shabouri and A.M. I. Mohamed, Bull. Fac. Sci., Assiut Univ., 21, 53 (1992).

11- P. D. Panzade and L. R. Mahadik, Indian Drugs, 36, 321 (1999).

12- V. Ulvi, J. Pharm. Biomed Anal., 17, 77 (1998).

13- A. Sachan, D. K. Jain and P. Trivedi, Indian Drugs, 34, 168 (1997).

14- W. X. Jin, L. L. Liu, H. S. Fang and Z. L. Liu, Yaowu Fenxi Zazhi, 17, 341 (1997). Anal. Abstr. 60, 5 G152 (1998).

15- R. B. Smith, R. V. Smith, G. J. Yakatan, J. Pharm. Sci., 65, 1208 (1976).

16- N. Erk and M. Kartal, Anal. Lett., 32, 1131 (1999).

17- I. E. Panderi, M. Parissi-Poulou, J. Pharm. Biomed. Anal., 21, 1017 (1999).

18- M. Kartal and N. Erk, J. Pharm. Biomed. Anal., 19, 477 (1999).

19- H. F. Yang, Y. F. Liu, Z. H. Wang and T. H. Ding, Sepu, 16, 158 (1998). Anal. Abstr., 60, 9G97 (1998).

20- W. R. Jin, X. Y. Ye, D. G. Yu, Q. Dong; Anal. Chim. Acta, 408, 257 (2000).

21- M. I. Maguregui, R. M. Jimenez and R. M. Alonso, J. Chromatogr. Sci. 36, 516 (1998).

22- I. E. Panderi, J. Pharm. Biomed. Anal., 21, 257 (1999).

23- C. V. N.Prasad, C. Parihar, K. Sunil and P. Parimoo, J. Pharm. Biomed. Anal., 17, 884 (1998).

24- V. Ulvi, Pharm. Pharmacol. Commun., 4, 193 (1998).

25- N. Erk, Anal. Lett., 31, 633 (1998).

26- N. Erk, J. Pharm. Biomed. Anal., 20, 155 (1999).
27- N. Erk, Anal. Lett., 32, 1371 (1999).

28- I. N. Papadoyannis, V. F. Samanidon, A. Georga and E. Georgarakis, J. Liq. Chromatogr. Relat. Technol., 21, 1671 (1998).

29- J. Ouyang, W. R. G.Baeyens, J. Delanghe, G. Van-derWeken, W. Van Daele, D. De Keukeleire and A. M. Garcia Campana, Anal. Chim. Acta, 386, 257 (1999).

30- G. V. Kanumula and B. Raman, Indian Drugs, 37, 38 (2000).

31- E. Martin, O. Hernandez, J. J. Arias and A. I. Jimenez, Microchem. J., 56, 207 (1997).

32- E. Martin, O. Hernandez, A. I. Jimenez, F. Jimenez and J. J. Arias, Anal. Lett., 31, 1857 (1998).

33- M. E. Martin, O. M. Hernandez, A. I. Jimenez, J. J. Arias and F. Jimenez, Anal. Chim Acta, 381, 247 (1999).

34- K. R. Beebe and B. R. Kowalski, Anal. Chem., 59, 1007 (1987).

35- K. Mahalanabis and D. Basu, Analyst, 114, 1311 (1989).

36- H. C. Goicoechea and A. C. Olivieri, Talanta, 47, 103 (1998).

37- C. Demir and R. G. Brereton; Analyst, 123, 181 (1998).

38- N. Capitan-Vallvey, M. Kalil, A. Deheidel, I. de Orbe and R. Avidad, Analyst, 124, 49 (1999).

39- M. J. Benito, M. C. Ortiz, M. S. Sanchez, L. A. Sarabia and M. Iniguez, Analyst, 124, 547 (1999).

40- J. A. Hernandez-Arteseros, R. Compano, R. Ferrer and M. D. Prat, Analyst, 125, 1155 (2000). 